\title{
Poly(urea-formaldehyde) microcapsules - synthesis and influence of stirring speed on capsules size
}

\author{
Patryk A. Bolimowski ${ }^{1) *}$, Rafał Kozera ${ }^{1)}$, Anna Boczkowska ${ }^{1)}$ \\ DOI: dx.doi.org/10.14314/polimery.2018.5.2
}

\begin{abstract}
Microcapsules from commercially available epoxy resin (Epidian $\left.{ }^{\circledast} 52\right)$ and an organic solvent (ethyl phenylacetate, EPA), for application to self-healing epoxides, were prepared. Poly(urea-formaldehyde) microcapsules containing the active ingredients were prepared using in situ polymerization in an oil-in-water emulsion. The prepared capsules were characterized by scanning electron microscope (SEM) for their surface morphology and size distribution. Thermogravimetric analysis (TGA) has been carried out to determine their thermal stability and maximum processing temperature. Moreover, the influence of stirring speed on their size distribution was investigated in predefined conditions. It is demonstrated that microcapsules can be easily prepared using the literature methodology and that the urea-formaldehyde polymer is a good barrier for the enclosed epoxy resin-organic solvent. Performed experiments suggest that size of microcapsules can be controlled by the stirring speed of the emulsion and that the capsules are thermally stable up to $140{ }^{\circ} \mathrm{C}$ for 24 hours. Additional studies showed that microcapsules exhibit excellent interface with a commercial epoxy resin matrix cured at elevated temperatures what is desired in their further application.
\end{abstract}

Keywords: self-healing materials, microcapsules, epoxy resin, thermal stability.

\section{Mikrokapsułki mocznikowo-formaldehydowe - synteza oraz wpływ prędkości mieszania na rozrzut wymiaru}

Streszczenie: Otrzymano polimerowe mikrokapsułki zawierające mieszaninę żywicy epoksydowej (Epidian $\left.{ }^{\circledast} 52\right)$ i rozpuszczalnika organicznego (fenylooctan etylu, EPA) przeznaczone do zastosowań w samonaprawiających się materiałach epoksydowych. Kapsułki przygotowano z wykorzystaniem techniki polikondensacji mocznika i formaldehydu w emulsji oleju w wodzie. Metodą skaningowej mikroskopii elektronowej (SEM) analizowano morfologię powierzchni wytworzonych kapsułek i określano rozrzut ich wymiarów. Stabilność kapsułek w podwyższonej temperaturze oraz maksymalną temperaturę przetwórstwa wyznaczano termograwimetrycznie (TGA). Badano też wpływ szybkości mieszania wyjściowej mieszaniny surowców na rozrzut wymiarów otrzymanych kapsułek. Stwierdzono, że stosowana żywica mocznikowo-formaldehydowa stanowi warstwę barierową (ścianę kapsułki) dla inkludowanych mieszanin epoksydów z rozpuszczalnikiem organicznym. Wykazano, że zastosowanie odpowiedniej prędkości mieszania składników podczas emulsyfikacji pozwala na zmniejszenie rozrzutu wymiarów kapsułek. Otrzymane kapsułki są termicznie stabilne do temperatury $140{ }^{\circ} \mathrm{C}$ w ciągu $24 \mathrm{~h}$. Stwierdzono też, że warstwa powierzchniowa kapsułek jest silne związana z żywicą epoksydową usieciowaną w podwyższonej temperaturze, co jest korzystne $w$ ich dalszych zastosowaniach.

Słowa kluczowe: materiały samonaprawiające, mikrokapsułki, żywica epoksydowa, stabilność temperaturowa.

Microencapsulation is an effective way of protecting active ingredients in a variety of fields such as medicine, agrochemicals, food additives, perfumes, and industrial chemicals [1-3]. Reactive chemicals often need shielding from surrounding environment so they can retain their

\footnotetext{
1) Warsaw University of Technology, Faculty of Materials Science and Engineering, Wołoska 141, 02-507 Warsaw, Poland.

*) Author for correspondence:

e-mail: patryk.bolimowski@gmail.com
}

activity during storage and perform required function after release. More recently, microencapsulation has attracted an interest in the field of self-healing materials [4-6]. Here, microcapsules are used to distribute the reactive ingredients within the material and to release it in response to external damages like micro-cracking or delamination. In the crack environment, the reactive ingredients undergo chemical reaction or physiochemical processes to form a new material that bridges the delaminated surfaces [4-6]. 
There is a number of techniques available in the literature to create liquid filled microcapsules and they vary in dependence on the required capsules characteristics, core material, and the release mode [1-3]. In the field of selfhealing, in situ polymerization in an oil-in-water emulsion is the most exploited to date [7-20]. Typical capsule shell materials include urea-formaldehyde (UF), urea-melamine-formaldehyde (UMF) and melamine-formaldehyde (MF), which have been proved promising for sequestration of various reactive chemicals including dicyclopentadiene/ethylidene-norbornene (DCPD/ENB) [21-23], organic solvents [24], epoxy resins [19, 25-27], and their crosslinkers such as amines [28], thiols [29], and glycidyl methacrylate [30].

In the classical approach, the reactive ingredients are first dispersed in an aqueous solution containing surfactant/stabilizer and monomeric shell wall components. After emulsification at desired conditions (volume, stirring rate), condensation of urea and formaldehyde and other compounds is triggered by increase of temperature $\left(55^{\circ} \mathrm{C}\right)$. As a result, low molecular weight prepolymer is formed in the aqueous phase, and collapses onto the oil and water interface. Upon continuing reaction, a solid and non-permeable shell made of crosslinked poly(urea-formaldehyde) is formed. In dependence on the requirements, microcapsules characteristics (diameter and shell wall thickness) can be easily controlled by adjusting the emulsification procedure, reaction time, temperature, core to shell reagent ratio, oil to water ratio and more importantly stirring speed $[25,31]$.

In this paper we describe a microencapsulation of commercially available epoxy resin (Epidian $\left.{ }^{\circledR} 52\right)$ and organic solvent (ethyl phenylacetate) in a poly(urea-formaldehyde) shell wall. Epoxy resin and the solvent were encapsulated since the system has been demonstrated before as promising healing agents for commercially available epoxides and in their fiber-reinforced polymer composites $[4,19,25,26,32-35]$. In this approach, microcapsules release the low viscosity epoxy resin into the crack environment after a damage. Later, the epoxy resin polymerizes in the presence of separately dispersed catalytic curing agents $[4,18,19,34-37]$, hardeners $[9,28,29,38]$ and residual matrix functionality $[8,39,40]$. Newly formed polymer bridges the fractured surfaces and restores the materials lost structural functionality. For the first time, commercial Epidian ${ }^{\circledR} 52$ epoxy resin is utilized as active agent in microencapsulation. Microcapsules were prepared according to the literature in situ polymerization in an oil-in-water emulsion [20] and characterized in terms of their size distribution, shell wall morphology and thermal stability. The literature methodol- ogy was modified, by adjusting the stirring speed, to prepare microcapsules with desired size distribution. It has to be borne in readers mind, that microcapsules characteristics are dependent on the core material characteristics and used equipment including reaction vessel geometry and size, stirrer geometry and processing temperature. To investigate whether the utilized shell material is robust to sustain processing conditions in a standard epoxy resin, dry microcapsules were embedded in standard epoxy resin (Epidian ${ }^{\circledR} 52$ ) crosslinked with amine hardener (Z-1), resin systems utilized in coatings, adhesives and fiber-reinforced polymer composites. The resin system was consolidated at moderate temperature $\left(60^{\circ} \mathrm{C}\right)$ according to manufacturer's recommendations [41]. The test demonstrated that microcapsules shell is robust to sustain the processing conditions, and brittle to rupture upon propagating crack when embedded in the model polymer.

\section{EXPERIMENTAL PART}

\section{Materials}

Ethyl phenylacetate [EPA, $\mathrm{C}_{6} \mathrm{H}_{5} \mathrm{CH}_{2} \mathrm{C}(\mathrm{O}) \mathrm{OC}_{2} \mathrm{H}_{5}$ ], urea $\left(\mathrm{NH}_{2} \mathrm{CONH}_{2}\right)$, poly(ethylene-alt-maleic anhydride) (EMA, $\bar{M}_{w}=100000-500000$, powder), resorcinol $\left[\mathrm{C}_{6} \mathrm{H}_{4}-1,3-(\mathrm{OH})_{2}\right]$, formaldehyde ( $37 \mathrm{wt} \%$ in $\mathrm{H}_{2} \mathrm{O} /$ methanol, $\mathrm{CH}_{2} \mathrm{O}$ ) and ammonium chloride $\left(\mathrm{NH}_{4} \mathrm{Cl}\right)$ were purchased from Sigma-Aldrich and used as received. Sodium hydroxide $(\mathrm{NaOH})$ was purchased from POCHS.A. and also used as received. Commercial epoxy resin - Epidian ${ }^{\circledR} 52$ and its hardener Z-1 were purchased from Ciech S.A.

\section{Microencapsulation}

$250 \mathrm{~cm}^{3}$ of deionized water containing $0.5 \mathrm{wt} \%$ of emulsion stabilizer (EMA) was prepared in a $1000 \mathrm{~cm}^{3}$ beaker. Subsequently, $5.0 \mathrm{~g}$ of urea, $0.5 \mathrm{~g}$ of resorcinol and $0.5 \mathrm{~g}$ of ammonium chloride were added and dissolved under continuous stirring (Table 1).

Next, $\mathrm{pH}$ of the water phase was adjusted by dropwise addition of $\mathrm{NaOH}(\approx 0.2 \mathrm{~N})$ to 3.40 and stirring speed was increased to desired rate (Table 2), and after $15 \mathrm{~min}$ utes, $60 \mathrm{~cm}^{3}$ of measured oil phase (Epidian ${ }^{\circledR} 52$ : EPA at $75: 25 \mathrm{wt} \%$ ratio) was added dropwise.

$12.68 \mathrm{~g}$ of $37 \%$ formaldehyde was added and temperature was increased to $55^{\circ} \mathrm{C}$. After 4 hours, the stirrer was stopped, and the microcapsule slurry was left in the water medium for 24 hours at room temperature. Microcapsules were then vacuum filtered and rinsed a few times with ethanol to remove residual water. The isolated cap-

$\mathrm{T}$ a b 1 e 1. Core and shell materials used in microencapsulation adapted from the literature [20]

\begin{tabular}{|c|c|c|c|c|c|c|}
\hline \multicolumn{2}{|c|}{ Oil phase $\left(60 \mathrm{~cm}^{3}\right)$} & \multicolumn{4}{|c|}{ Aqueous phase $\left(250 \mathrm{~cm}^{3}\right)$} & Emulsifier \\
\hline $\begin{array}{c}\text { Epidian }^{\circledR} 52 \\
\text { wt } \%\end{array}$ & $\begin{array}{l}\mathrm{EPA} \\
\text { wt \% }\end{array}$ & $\begin{array}{c}\text { Urea } \\
\mathrm{g}\end{array}$ & $\begin{array}{c}\text { Formaldehyde } \\
\mathrm{g}\end{array}$ & $\begin{array}{c}\text { Resorcinol } \\
\mathrm{g}\end{array}$ & $\begin{array}{c}\mathrm{NH}_{4} \mathrm{Cl} \\
\mathrm{g}\end{array}$ & $\begin{array}{l}\text { EMA } \\
\text { wt \% }\end{array}$ \\
\hline 75 & 25 & 5.0 & 12.68 & 0.5 & 0.5 & 0.5 \\
\hline
\end{tabular}


T a b l e 2. Stirring speed, $\mathrm{pH}$, temperature, and drying conditions

\begin{tabular}{c|c|c|c|c}
\hline No. & $\begin{array}{c}\text { Agitation } \\
\text { rpm }\end{array}$ & $\mathrm{pH}$ & $\begin{array}{c}\text { Temperature } \\
{ }^{\circ} \mathrm{C}\end{array}$ & $\begin{array}{c}\text { Drying } \\
\mathrm{T} / \mathrm{p} / \mathrm{t}\end{array}$ \\
\hline P1 & 310 & & & \\
P2 & 450 & $3.3-3.5$ & 55 & $55^{\circ} \mathrm{C} / \mathrm{vac} / 24 \mathrm{~h}$ \\
P3 & 550 & & & \\
\hline
\end{tabular}

sules were post heated at $55^{\circ} \mathrm{C}$ in an oven for another 24 hours and weighed. Yield of microcapsules was calculated relatively to mass of used core and shell materials. Stirring speed, $\mathrm{pH}$, temperature, and drying conditions for prepared microcapsules are summarized in Table 2.

\section{Methods of testing}

\section{Microcapsules size distribution analysis}

Microcapsule diameter and size distribution were analyzed using a portable scanning electron microscope (HITACHI TM3000). Prior to the microscopy, dry powder of microcapsules was placed on a conductive stub and sputter coated with a thin layer of $\mathrm{Pt} / \mathrm{Ag}$. For the size distribution, image analysis software (ImageJ) was used. Mean diameter and size distribution were obtained from at least 500 measurements.

\section{Thermal analysis}

Thermal analysis was performed using thermogravimetric analysis (TGA) on TA Instruments Q500 TGA. Mass loss of dry capsule powder was recorded under non-isothermal conditions from $25^{\circ} \mathrm{C}$ to $600{ }^{\circ} \mathrm{C}$ at a heating rate of $10^{\circ} \mathrm{C} / \mathrm{min}$. The analysis was also performed for separated core resin-solvent and shell poly(urea-formaldehyde). A small amount of dry microcapsules was placed in a syringe pump and crushed gently. Core epoxy resin-organic solvent mixture was then filtrated to remove any residual shell material and analyzed using TGA. Remaining shell polymer was washed several times in ethanol to remove epoxy resin and dried overnight at $40^{\circ} \mathrm{C}$ prior the analysis.

Additionally, isothermal measurements were performed for dry microcapsules at 60, 80, 100, 120 and $140{ }^{\circ} \mathrm{C}$ for $24 \mathrm{~h}$. The mass loss was calculated from the initial mass of microcapsules and the mass of microcapsules after the isotherm.

\section{Incorporation into epoxy resin}

Dry microcapsules were mixed with Epidian ${ }^{\circledast} 52$ epoxy resin and compatible Z-1 hardener at prescribed loadings (100 : 13). 1 wt \% of microcapsules was mixed with the resin, degassed for 20 minutes under vacuum and left for $24 \mathrm{~h}$ at $60^{\circ} \mathrm{C}$ for complete curing. Later, the consolidated sample was fractured, gently washed with acetone to remove core epoxy resin-solvent, dried and analyzed using a scanning electron microscope (SEM). Prior to the SEM analysis, the sample was placed on a microscope stub and sputter coated with a thin layer of Pt/Ag.

\section{RESULTS AND DISCUSSION}

\section{Microencapsulation of epoxy resin and organic solvent mixture}

Microcapsules containing a solution of commercial epoxy resin (Epidian ${ }^{\circledR} 52$ ) and an organic solvent (ethyl phenylacetate) at $75: 25$ weight ratio were successfully synthesized using in situ polymerization in an oil-in-water emulsion [20]. Exemplary size distribution and shell wall morphology of capsules prepared at $310 \mathrm{rpm}$ are illustrated in Fig. 1.

\section{Microcapsules size distribution}

The dependence of microcapsules size distribution on the stirring speed is illustrated in Fig. 1d. Table 3 summarizes results collected for synthesis performed at 310, 450 and $550 \mathrm{rpm}$. The collected data suggest that at higher stirring rates, the microcapsules diameter decreases and size distribution becomes narrower. The mean diameter measured for capsules prepared at $310 \mathrm{rpm}$ was $150 \pm 120 \mu \mathrm{m}$ and decreased with the stirring speed to $90 \pm 80 \mu \mathrm{m}$ and $60 \pm 30 \mu \mathrm{m}$ for 450 and $550 \mathrm{rpm}$, respectively. Increasing the stirring speed, higher shear forces are generated within the reaction volume and finer oil droplets are created. After the shell formation, the liquid core is encapsulated and resulting microcapsules exhibit decreased size. However, at reduced agitation rates below $310 \mathrm{rpm}$, the microencapsulation was unsuccessful as the active material escaped from the emulsion, coalesced and impeded the shell formation process. In addition, increasing the agitation rate above $550 \mathrm{rpm}$, resulted vortex in the reaction vessel causes undesired turbulent flow, what puts a limit on the microencapsulation procedure.

\section{Shell wall morphology}

Scanning electron microscope was used to investigate the microcapsules shell wall morphology (Figs. 1, 2 and 3). Microcapsules illustrated in Fig. 1 exhibit a smooth exterior shell made of the amino resin depositing uniformly onto the oil and water interface. It suggests that the shell

T a b l e 3. Yield and mean diameter for microcapsules prepared at various stirring speed

\begin{tabular}{c|c|c}
\hline No. & $\begin{array}{c}\text { Microcapsules yield } \\
\%\end{array}$ & $\begin{array}{c}\text { Mean diameter } \\
\mu \mathrm{m}\end{array}$ \\
\hline P1 & 71.2 & $150 \pm 120$ \\
P2 & 74.5 & $90 \pm 80$ \\
P3 & 82.1 & $60 \pm 30$ \\
\hline
\end{tabular}


a)

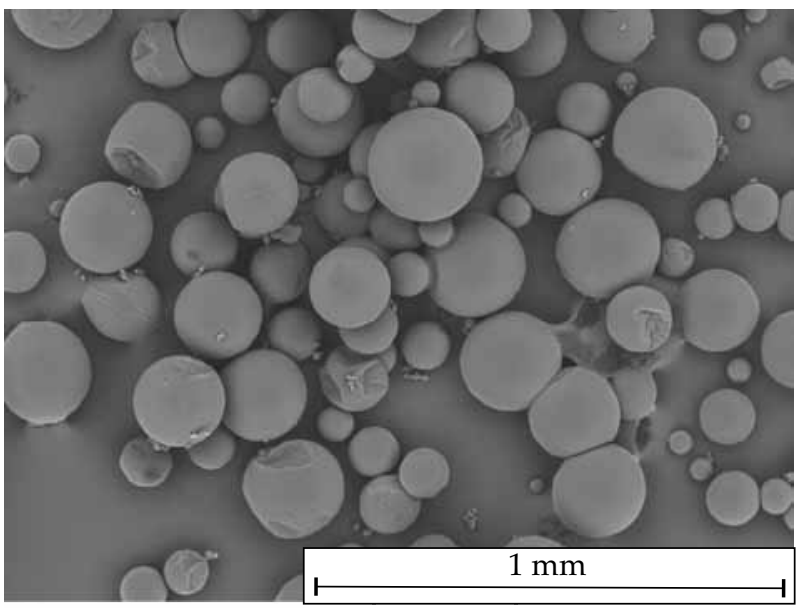

c)

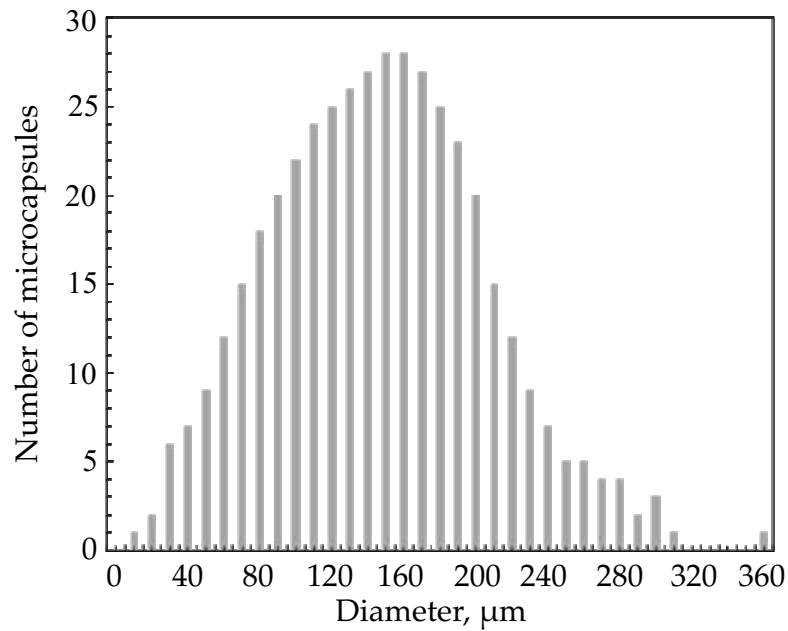

b)

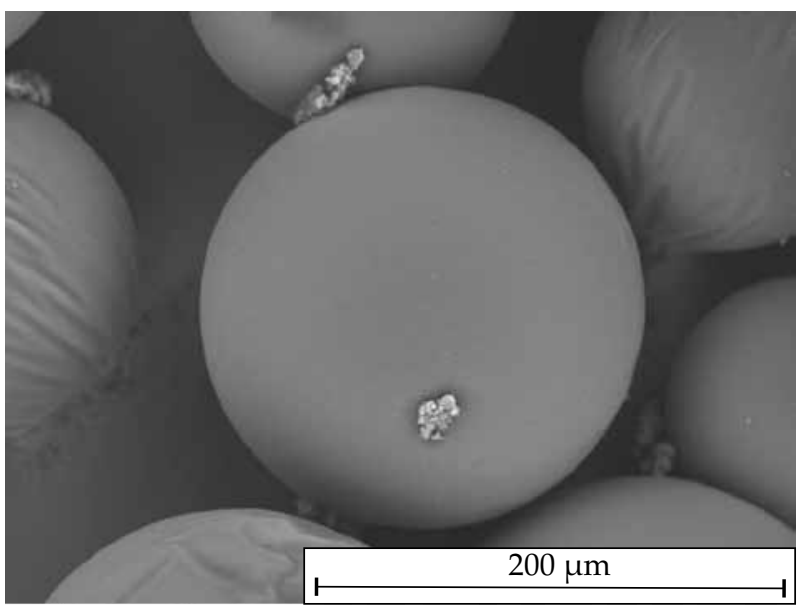

d)

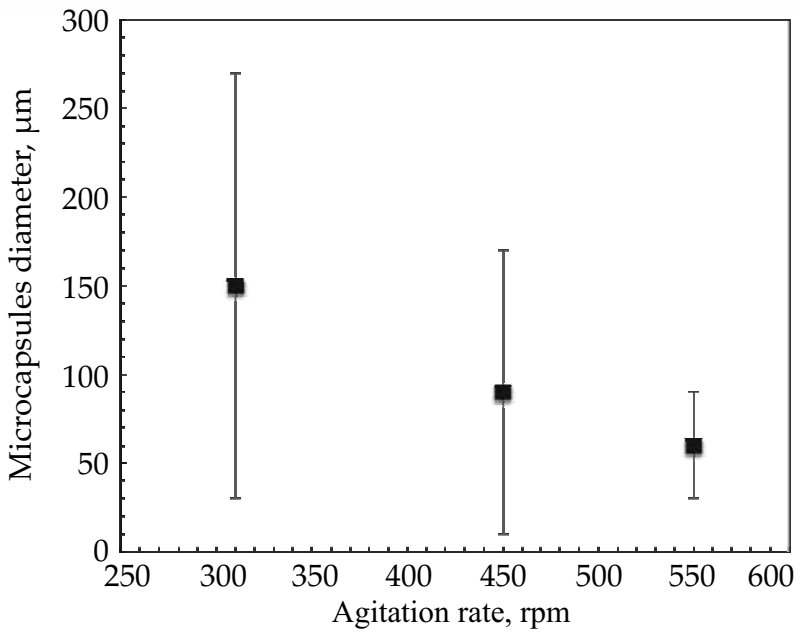

Fig. 1. a, b) Poly(urea-formaldehyde) microcapsules filled with Epidian ${ }^{\circledR}$ 52-EPA prepared using in situ polymerization in an oil-in-water emulsion at $310 \mathrm{rpm}, \mathrm{c}$ ) graph illustrating size distribution, d) graph illustrating the size distribution dependence on stirring speed

forming materials are fully consumed during encapsulation. In the case of capsules prepared at 450 and $550 \mathrm{rpm}$, the shell wall is comprised of two distinct regions that include a thin continuous inner wall, separating the core material from the environment, and a thicker rough exterior layer of the depositing polymer.

The continuous membrane is formed as urea and formaldehyde react in the aqueous phase to form a low molecular weight prepolymer. The prepolymer is then deposited onto the water and oil interface. Rough exterior layer is created as the prepolymer grows in size and collapses onto the capsules surface [20,25]. This shell morphology is desired for application in damage responsive materials as it increases the bonding area with the host material and facilitates the microcapsules rupture by propagating crack.

\section{Yield analysis}

The yield of microencapsulation was determined for all prepared batches and is reported in Table 3. The maximum $(82.1 \%)$ was calculated for capsules synthesized at $550 \mathrm{rpm}$ and decreases to 74.5 and $71.2 \%$ for batches prepared at 450 and $310 \mathrm{rpm}$, respectively. At low stirring speed, the size of oil droplets generated in the emulsion is larger and causes creation of thin wall onto their surface. These capsules are easily ruptured while vigorously stirred, what results in release the core material. The liquid core is later washed with ethanol during further processing. A good balance is achieved at $550 \mathrm{rpm}$ as the size of resulted oil droplets is easily covered with a thick and porous shell, able to sustain the vigorous stirring.

\section{Thermal stability analysis}

To investigate the thermal stability of microcapsules, thermogravimetric analysis was performed for P3 batch. Non-isothermal analysis was performed in air conditions from 25 to $600{ }^{\circ} \mathrm{C}$ for capsules and separately core and shell materials (Fig. 4).

The first significant mass loss observed for microcapsules $\left(230{ }^{\circ} \mathrm{C}\right)$ is associated with the decomposition of the shell polymer and release of liquid core. Subsequently, a rapid mass reduction from $230^{\circ} \mathrm{C}$ to $300^{\circ} \mathrm{C}$ corresponds to evaporation of the organic solvent (EPA) and partial decomposition of the Epidian ${ }^{\circledast} 52$ liquid. The remaining mass decom- 


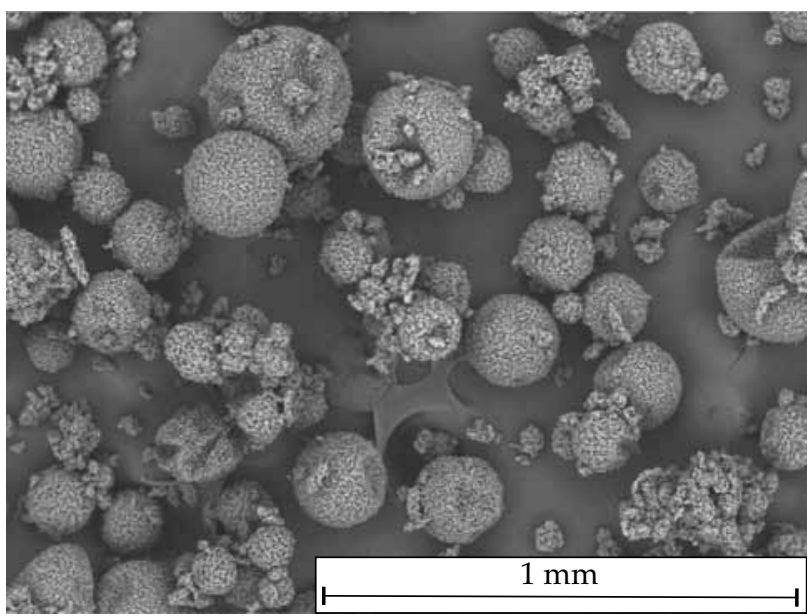

c)

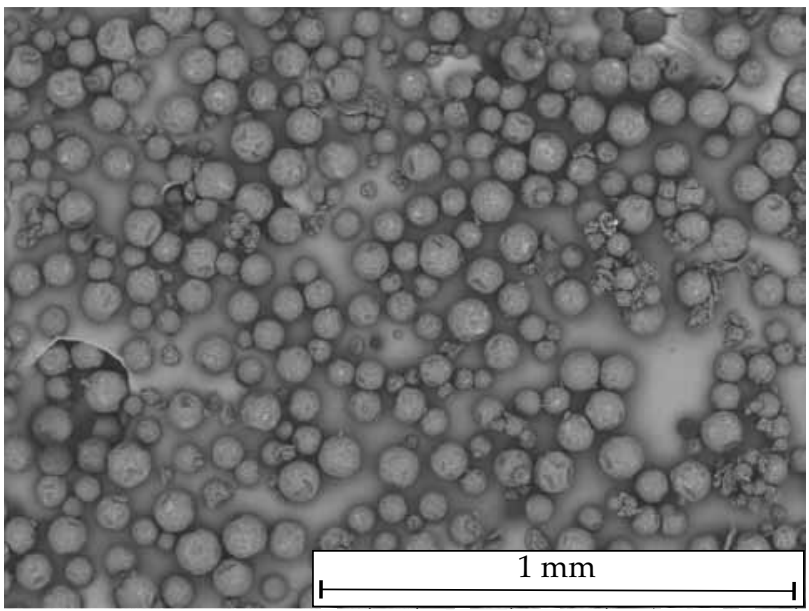

b)

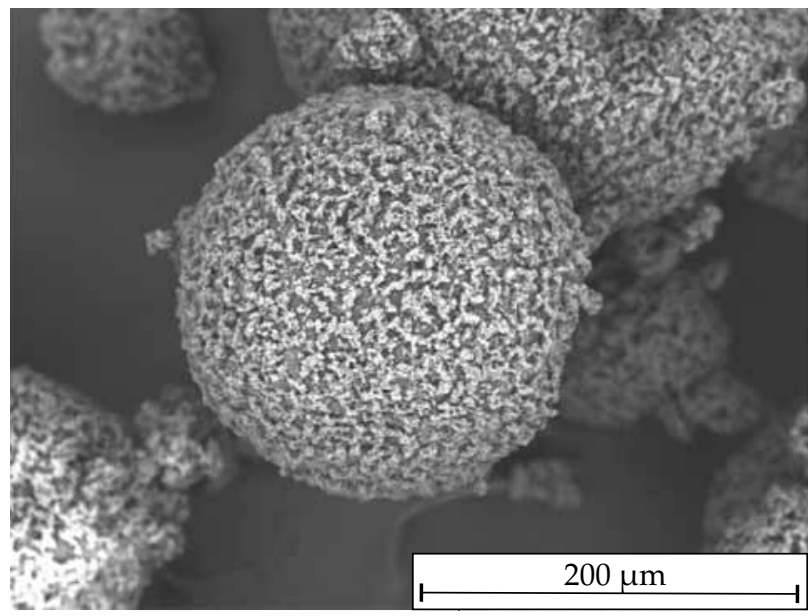

d)

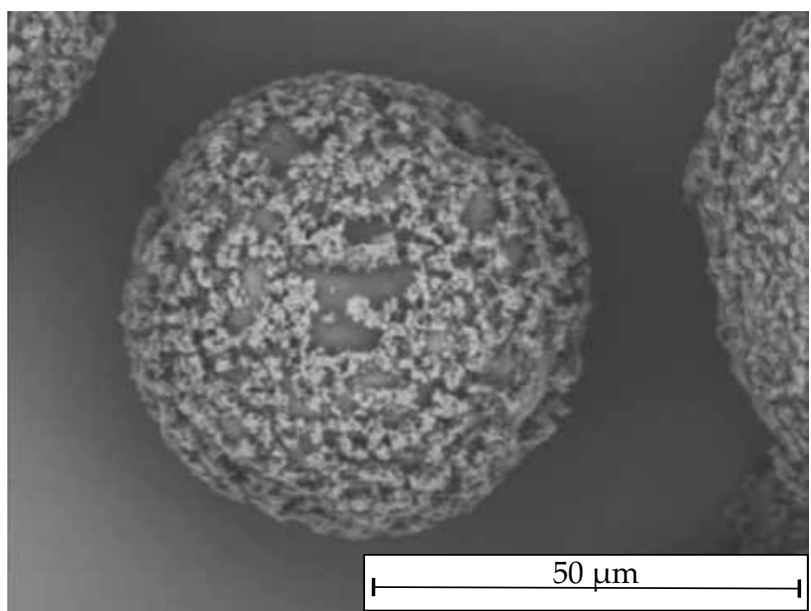

Fig. 2. Poly(urea-formaldehyde) microcapsules filled with Epidian ${ }^{\circledR}$ 52-EPA prepared using in situ polymerization in an oil-in-water emulsion at a, b) $450 \mathrm{rpm}, \mathrm{c}$, d) $550 \mathrm{rpm}$

posing above $310{ }^{\circ} \mathrm{C}$ is associated with decomposition of homopolymerized epoxy resin. A similar trend is observed for the mixture of epoxy resin and organic solvent. Here, EPA solvent evaporates first as is not protected in the shell. In the following step, epoxy resin is partially decomposed,

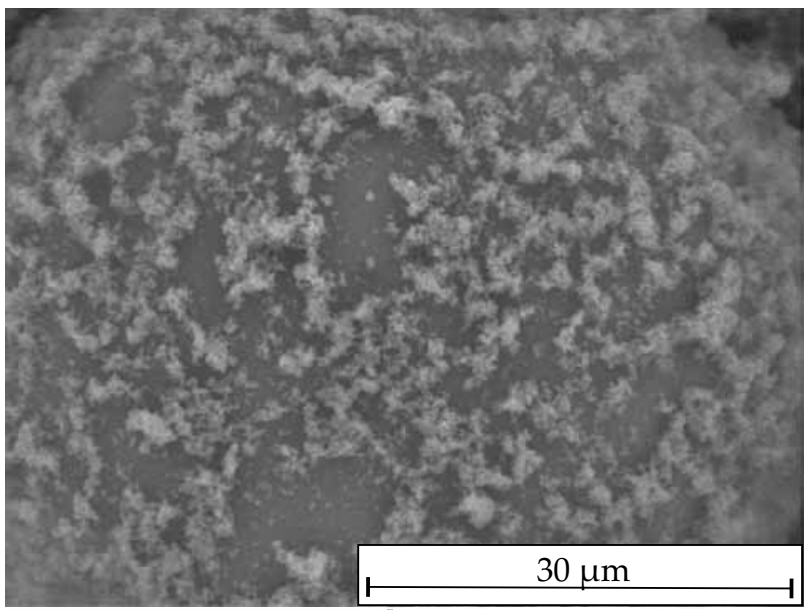

Fig. 3. Shell wall morphology of poly(urea-formaldehyde) microcapsules synthesized at $450 \mathrm{rpm}$ what results in the mass reduction, and partially homopolymerized. The weight loss presented here suggests that the core materials is composed in $24.94 \%$ of more volatile EPA and $75.06 \%$ of the active epoxy resin (Epidian ${ }^{\circledR} 52$ ). In addition, the analysis performed for poly(urea-formaldehyde)

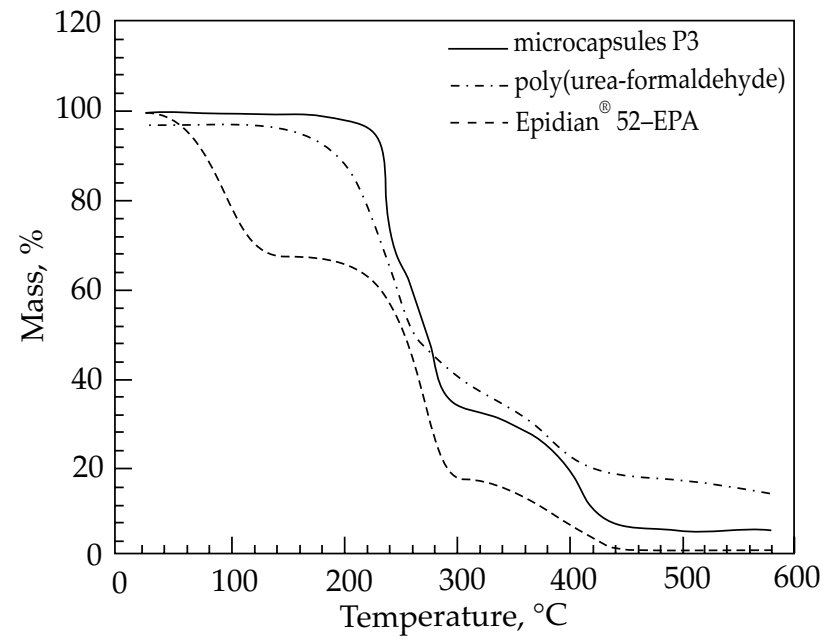

Fig. 4. Thermogravimetric analysis (TGA) for microcapsules filled with Epidian ${ }^{\circledR} 52$ and EPA solvent, performed from room temperature to $600{ }^{\circ} \mathrm{C}$ 
T a b l e 4. Mass loss of microcapsules (P3) during 24 hours isotherm performed at various temperatures

\begin{tabular}{c|c}
\hline Temperature, ${ }^{\circ} \mathrm{C}$ & Mass loss, $\%$ \\
\hline 60 & 0.18 \\
80 & 0.29 \\
100 & 0.47 \\
120 & 2.10 \\
140 & 3.30 \\
160 & 20.30 \\
\hline
\end{tabular}

Exemplary heating cycle: temperature ramp from $R T$ to $60^{\circ} \mathrm{C}$ at $2{ }^{\circ} \mathrm{C} / \mathrm{min}$, isotherm 24 hours at $60^{\circ} \mathrm{C}$, ramp from $60{ }^{\circ} \mathrm{C}$ to $R T$ at $2{ }^{\circ} \mathrm{C} / \mathrm{min}$.

suggests that the polymer is stable to maximum $170{ }^{\circ} \mathrm{C}$. Therefore, it is undesired to use the microcapsules in manufacturing requiring higher temperatures than $170^{\circ} \mathrm{C}$.

Isothermal experiments were performed to further investigate the thermal stability. The mass loss was determined for microcapsules P3 heated at 60, 80, 100, 120, 140 and $160^{\circ} \mathrm{C}$ for 24 hours (Fig. 5). Analyzing data enclosed in the Table 4, it is observed that microcapsules lose from 0.2 to $3.5 \%$ of their total mass for temperatures from 60 to $140{ }^{\circ} \mathrm{C}$. This minimal mass reduction is associated with removal of residual water from the shell wall and further crosslinking of poly(urea-formaldehyde) $[20,25]$. Increasing the temperature to $160^{\circ} \mathrm{C}$, the maximum $20.30 \%$ mass loss was recorded and it is associated with softening of the shell material and core release. Organic solvent (EPA) evaporates in this temperature what causes the significant weight loss.

\section{Incorporation into epoxy matrix}

Figure 6 illustrates a cross-sectional area of the Epidian ${ }^{\circledR} 52-Z-1$ containing $1 \mathrm{wt} \%$ of P3 microcapsules. The resin system was cured at $60^{\circ} \mathrm{C}$ for 24 hours in air conditions and manually fractured before the SEM analysis.

a)

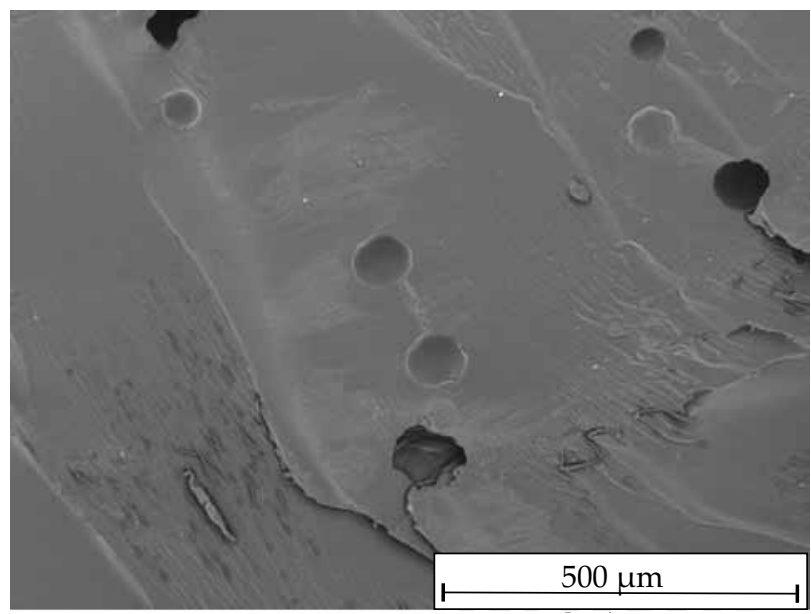

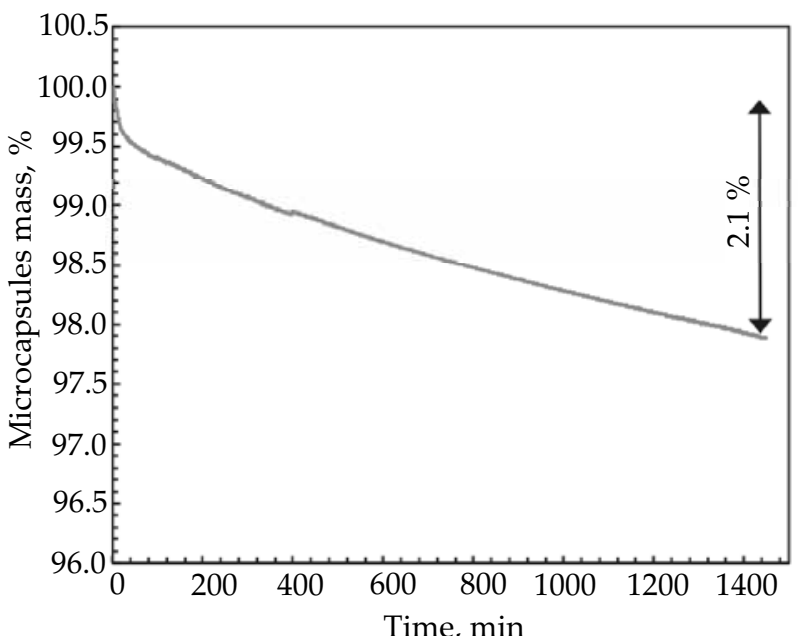

Fig. 5. Representative isothermal TGA analysis performed at $120^{\circ} \mathrm{C}$ for $\mathrm{P} 3$ microcapsules

The presence of ruptured microcapsules in the fracture plane suggests that the shell polymer is brittle and exhibits a good interface strength with the matrix epoxy resin. It is necessary as capsules after damage have to rupture and release the healing agent. The rough polymeric surface provides extra mechanical bonding to the epoxy matrix. When the porous surface is infiltrated with the liquid matrix, after consolidation provides increased bonding area as well.

\section{CONCLUSIONS}

In the presented work, epoxy resin-organic solvent microcapsules were successfully synthesized using in situ polymerization adapted from the literature [20]. Microcapsules ranged from 30 to $270 \mu \mathrm{m}$ in diameter and exhibited a smooth polymeric surface suggesting full consumption of shell materials during synthesis. It is demonstrated that the size of microcapsules and its distribution can be easily controlled by the stirring rate at emulsification stage.

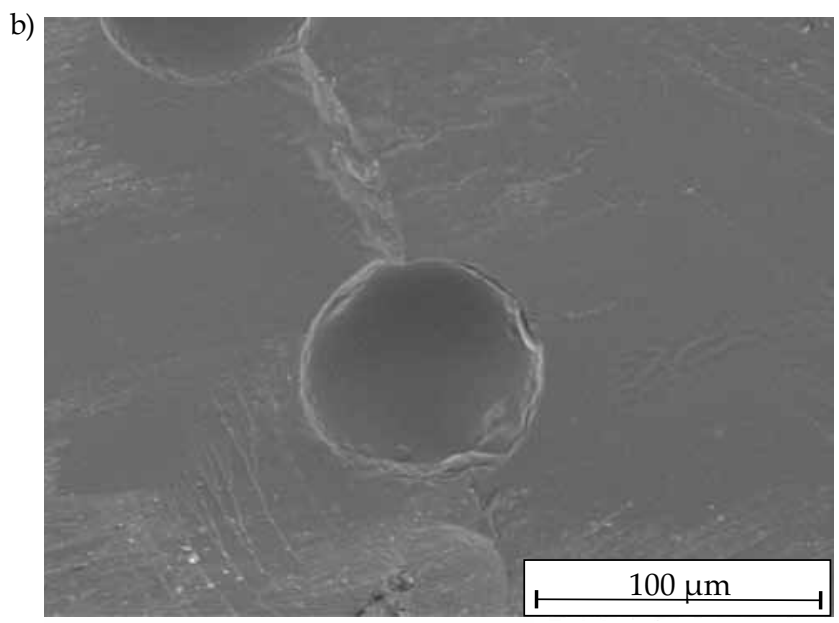

Fig. 6. a) Ruptured poly(urea-formaldehyde) microcapsules in a crack plane of a standard epoxy resin, b) a single microcapsules in a crack plane 
The performed TGA analysis suggests that the microcapsules are thermally stable to sustain temperature condition of many commercially available epoxy polymers and composites. Temperature of $140{ }^{\circ} \mathrm{C}$ was identified as the maximum processing temperature above which the shell polymer softens and releases slowly the encapsulated core material. Below the temperature, poly(urea-formaldehyde) is stable and successfully protects the epoxy resin-solvent mixture from the environment and during fabrication. The performed TGA analysis also confirmed the presence of both encapsulated core materials (Epidian ${ }^{\circledR} 52$ and EPA) in desired weight ratio $(75: 25)$.

In addition, microcapsules were successfully embedded in a standard epoxy resin (Epidian ${ }^{\circledR} 52-Z-1$ ) and consolidated at elevated temperature $\left(60^{\circ} \mathrm{C}\right)$ for 24 hours. The presence of ruptured microcapsules in the fracture plane suggests that the used shell material is brittle, breaks upon a propagating crack, and releases the encapsulated core.

In general, narrow size distribution, high thermal stability, bonding to the matrix, and rupture upon fracture were demonstrated in the study, and make the synthesized microcapsules as promising to be applied in self-healing epoxy polymers, adhesives, coatings and fiber-reinforced polymer composites. Therefore, prepared microcapsules will be combined with a selected catalytic curing agent or hardener, and utilized in epoxy based fiber-reinforced polymer composites to demonstrate their self-healing potential.

This work has been financed by the National Centre for Research and Development in Poland as grant No. PBS3/ A9/30/2015.

\section{REFERENCES}

[1] Ghosh S.K.: "Functional Coatings: by Polymer Microencapsulation”, Wiley-VCH Verlag GmbH \& Co. KGaA, Weinheim 2006.

[2] Benita S.: "Microencapsulation: Methods and Industrial Applications, Second Edition", CRC Press, New York 2005.

[3] Paulo F., Santos L.: Materials Science and Engineering: C 2017, 77, 1327. http://dx.doi.org/10.1016/j.msec.2017.03.219

[4] Binder W.H.: "Self-healing Polymers: From Principles to Application", Wiley-VCH Verlag GmbH \& Co. KGaA, Weinheim 2013.

[5] Blaiszik B.J., Kramer S.L.B., Olugebefola S.C. et al.: Annual Review of Materials Research 2010, 40, 179.

h t t p://dx.doi.org/10.1146/annurev-matsci-070909-104532

[6] Bekas D.G., Tsirka K., Baltzis D., Paipetis A.S.: Composites Part B: Engineering 2016, 87, 92. http://dx.doi.org/10.1016/j.compositesb.2015.09.057

[7] Fan C., Zhou X.: Colloids Surfaces A: Physicochemical and Engineering Aspects 2010, 363, 49. https://doi.org/10.1016/j.colsurfa.2010.04.012
[8] Neuser S., Manfredi E., Michaud V.: Materials Chemistry and Physics 2014, 143, 1018.

https://doi.org/10.1016/j.matchemphys.2013.10.041

[9] McIlroy D.A., Blaiszik B.J., Caruso M.M. et al.: Macromolecules 2010, 43, 1855.

http://dx.doi.org/10.1021/ma902251n

[10] Caruso M.M., Blaiszik B.J., Jin H. et al.: ACS Applied Materials \& Interfaces 2010, 2, 1195.

http://dx.doi.org/10.1021/am100084k

[11] Hu J., Chen H.Q., Zhang Z.: Materials Chemistry and Physics 2009, 118, 63. https://doi.org/10.1016/j.matchemphys.2009.07.004

[12] Li W., Zhu X., Zhao N. et al.: Materials 2016, 9, 152. http://dx.doi.org/10.3390/ma9030152

[13] Zhu D.Y., Rong M.Z., Zhang M.Q.: Progress in Polymer Science 2015, 49-50, 175. https://doi.org/10.1016/j.progpolymsci.2015.07.002

[14] Xing S., Yang J., Huang Y. et al.: Materials \& Design 2015, 85, 661. https://doi.org/10.1016/j.matdes.2015.07.098

[15] Jones A.R., Watkins C.A., White S.R., Sottos N.R.: Polymer 2015, 74, 254. https://doi.org/10.1016/j.polymer.2015.07.028

[16] Shahabudin N., Yahya R., Gan S.N.: Materials Today: Proceedings 2016, 3, S88. https://doi.org/10.1016/j.matpr.2016.01.012

[17] Cai X., Fu D., Qu A.: Composite Interfaces 2015, 22, 837. http://dx.doi.org/10.1080/09276440.2015.1066149

[18] Everitt D.T., Coope T.S., Trask R.S. et al.: Smart Materials and Structures 2015, 24, 055004. http://dx.doi.org/10.1088/0964-1726/24/5/055004

[19] Bolimowski P.A., Wass D.F., Bond I.P.: Smart Materials and Structures 2016, 25, 084009. http://dx.doi.org/10.1088/0964-1726/25/8/084009

[20] Brown E.N., Kessler M.R., Sottos N.R., White S.R.: Journal of Microencapsulation 2003, 20, 719. https://doi.org/10.3109/02652040309178083

[21] Brown E.N., White S.R., Sottos N.R.: Journal of Materials Science 2006, 41, 6266. http://dx.doi.org/10.1007/s10853-006-0512-y

[22] Keller M.W., White S.R., Sottos N.R.: Advanced Functional Materials 2007, 17, 2399. http://dx.doi.org/10.1002/adfm.200700086

[23] Jackson A.C., Bartelt J.A., Marczewski K. et al.: Macromolecular Rapid Communications 2010, 32, 82. http://dx.doi.org/10.1002/marc.201000468

[24] Caruso M.M., Delafuente D.A., Ho V. et al.: Macromolecules 2007, 40, 8830. http://dx.doi.org/10.1021/ma701992z

[25] Bolimowski P.A., Bond I.P., Wass D.F.: Philosophical Transactions of the Royal Society A 2015, 374, 20150083. http://dx.doi.org/10.1098/rsta.2015.0083

[26] Coope T.S., Mayer U.F.J., Wass D.F. et al.: Advanced Functional Materials 2011, 24, 4624. http://dx.doi.org/10.1002/adfm.201101660

[27] Yin T., Rong M.Z., Zhang M.Q., Yang G.C.: Composites Science and Technology 2007, 67, 201. 
https://doi.org/10.1016/j.compscitech.2006.07.028

[28] Jin H., Mangun C.L., Stradley D.S. et al.: Polymer 2012, $53,581$.

http://dx.doi.org/10.1016/j.polymer.2011.12.005

[29] Yuan Y.C., Rong M.Z., Zhang M.Q. et al.: Macromolecules 2008, 41, 5197.

http://dx.doi.org/10.1021/ma800028d

[30] Meng L.M., Yuan Y.C., Rong M.Z., Zhang M.Q.: Journal of Materials Chemistry 2010, 20, 6030. http://dx.doi.org/10.1039/c0jm00268b

[31] Cosco S., Ambrogi V., Musto P., Carfagna C.: Journal of Applied Polymer Science 2007, 105, 1400. http://dx.doi.org/10.1002/app.26263

[32] Hillewaere X.K.D., Du Prez F.E.: Progress in Polymer Science 2015, 49-50, 121. https://doi.org/10.1016/j.progpolymsci.2015.04.004

[33] Billiet S., Hillewaere X.K.D., Teixeira R.F.A., Du Prez F.E.: Macromolecular Rapid Communications 2013, 34, 290. http://dx.doi.org/10.1002/marc.201200689

[34] Everitt D.T., Luterbacher R., Coope T.S. et al.: Polymer 2015, 69, 283.

https://doi.org/10.1016/j.polymer.2015.02.047
[35] Coope T.S., Wass D.F., Trask R.S., Bond I.P.: Smart Materials and Strucutres 2014, 23, 115002. http://dx.doi.org/10.1088/0964-1726/23/11/115002

[36] Xiao D.S., Yuan Y.C., Rong M.Z., Zhang M.Q.: Polymer 2009, 50, 2967. https://doi.org/10.1016/j.polymer.2009.04.029

[37] Xiao D.S., Yuan Y.C., Rong M.Z., Zhang M.Q.: Advanced Functional Materials 2009, 19, 2289. http://dx.doi.org/10.1002/adfm.200801827

[38] Yuan Y.C., Ye Y., Rong M.Z. et al.: Smart Materials and Structures 2011, 20, 015024. http://dx.doi.org/10.1088/0964-1726/20/1/015024

[39] Caruso M.M., Blaiszik B.J., White S.R. et al.: Advanced Functional Materials 2008, 18, 1898. http://dx.doi.org/10.1002/adfm.200800300

[40] Kirkby E.L., Michaud V.J., Månson J-A.E. et al.: Polymer 2009, 50, 5533. https://doi.org/10.1016/j.polymer.2009.05.014

[41] http://ciechgroup.com/produkty/chemia-organiczna/ zywice/zywice-epoksydowe/ (access date 9.09.2017)

Received 31 VII 2017.

\section{Cracow University of Technology, \\ Faculty of Chemical Engineering and Technology invites to the $9^{\text {th }}$ Conference}

\section{GREEN CHEMISTRY AND NANOTECHNOLOGIES IN POLYMERIC MATERIALS}

\section{Poland, Cracow, October 10-12, 2018}

Conference dedicated to recent developments in polymer science and technology combines two popular areas of current research: the green approach utilizing renewable resources and mild reaction conditions together with innovative nanotechnologies enabling to design novel polymer materials with advanced properties.

\section{Topics:}

- Renewable raw materials - natural polymers and fibers

- Bio-based monomers and polymers

- Bio-based blends, composites and hybrids

- Biodegradation, LCA and environmental issues

- Sustainable bioplastics for packaging

- Eco-friendly synthesis of polymers (supercritical $\mathrm{CO}_{2}$, microwaves, sonication, enzymatic catalysis)

- Nanostructured polymers

- Biocomposites and nanocomposites

- Synthesis and surface modification of nanofillers

- Polymer nanofibers

- Sustainable nanomaterials

- Polymer processing

- Porous polymeric materials

Contact: Aleksander Prociak, + 481262830 16, aprociak@pk.edu.pl Maria Kurańska, + 481262827 47, maria.kuranska@gmail.com 